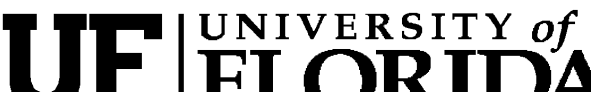 FLORIDA \\ IFAS Extension
}

\section{Smart Irrigation Controllers: How Do Soil Moisture Sensor (SMS) Irrigation Controllers Work?1}

\author{
Michael D. Dukes, Mary Shedd, and Bernard Cardenas-Lailhacar²
}

This article is part of a series on smart irrigation

controllers. The rest of the series can be found at

http://edis.ifas.ufl.edu/

TOPIC_SERIES_Smart_Irrigation_Controllers.

\section{Introduction}

Water is required for the basic growth and maintenance of turfgrass and other landscape plants. When a sufficient amount of water is not present for plant needs, then stress can occur and ultimately lead to reduced quality or death. Irrigation is common in Florida landscapes because of sporadic rainfall and the low water holding capacity of sandy soil. This inability of many of Florida soils to hold substantial water can lead to plant stress after only a few days without rainfall or irrigation.

Water conservation is a growing issue in Florida due to increased demands from a growing population. One of the areas with the largest potential for reducing water consumption is residential outdoor water use, which accounts for up to half of publicly supplied drinking water. Most new homes built in
Florida have automated irrigation systems. These irrigation systems use an irrigation timer to schedule irrigation (see Irrigation System Controllers http://www.edis.ifas.ufl.edu/ae077 for more information on timers). These automated irrigation systems have been shown to use $47 \%$ more water on average than sprinkler systems that are not automated (i.e. hose and sprinkler), which can be attributed largely to the tendency to set irrigation controllers and not readjust for varying weather conditions. Irrigation control technology that improves water application efficiency is now available. In particular, soil moisture sensors (SMS) can reduce the number of unnecessary irrigation events.

\section{How Soil Moisture Sensor Systems Work}

Most soil moisture sensors are designed to estimate soil volumetric water content based on the dielectric constant (soil bulk permittivity) of the soil. The dielectric constant can be thought of as the soil's ability to transmit electricity. The dielectric constant

1. This document is AE437, one of a series of the Agricultural and Biological Engineering Department, Florida Cooperative Extension Service, Institute of Food and Agricultural Sciences, University of Florida. Original publication date February 2009. Revised March 2009. Visit the EDIS Web Site at http://edis.ifas.ufl.edu.

2. Michael D. Dukes, associate professor; Mary Shedd, graduate research assistant; Bernard Cardenas-Lailhacar, research associate; Department of Agricultural and Biological Engineering; Florida Cooperative Extension Service, Institute of Food and Agricultural Sciences, University of Florida, Gainesville, FL 32611.

The use of trade names in this publication is solely for the purpose of providing specific information. UF/IFAS does not guarantee or warranty the products named, and references to them in this publication does not signify our approval to the exclusion of other products of suitable composition.

The Institute of Food and Agricultural Sciences (IFAS) is an Equal Opportunity Institution authorized to provide research, educational information and other services only to individuals and institutions that function with non-discrimination with respect to race, creed, color, religion, age, disability, sex, sexual orientation, marital status, national origin, political opinions or affiliations. U.S. Department of Agriculture, Cooperative Extension Service, University of Florida, IFAS, Florida A. \& M. University Cooperative Extension Program, and Boards of County Commissioners Cooperating. Millie Ferrer, Interim Dean 
of soil increases as the water content of the soil increases. This response is due to the fact that the dielectric constant of water is much larger than the other soil components, including air. Thus, measurement of the dielectric constant gives a predictable estimation of water content. For more information on soil moisture sensors see, Field Devices For Monitoring Soil Water Content http://edis.ifas.ufl.edu/ae266.

Bypass type soil moisture irrigation controllers use water content information from the sensor to either allow or bypass scheduled irrigation cycles on the irrigation timer (Figures 1 and 2). The SMS controller has an adjustable threshold setting and, if the soil water content exceeds that setting, the event is bypassed. The soil water content threshold is set by the user. Another type of control technique with SMS devices is "on-demand" where the controller initiates irrigation at a low threshold and terminates irrigation at a high threshold. The "on-demand" SMS controller concept is discussed in What Makes an Irrigation Controller Smart?

http://www.edis.ifas.ufl.edu/ae442.

\section{Sensor Installation}

A single sensor can be used to control the irrigation for many zones (where an irrigation zone is defined by a solenoid valve) or multiple sensors can be used to irrigate individual zones. In the case of one sensor for several zones, the zone that is normally the driest, or most in need of irrigation, is selected for placement of the sensor in order to ensure adequate irrigation in all zones.

Some general rules for the burial of the soil moisture sensor are:

- Soil in the area of burial should be representative of the entire irrigated area.

- Sensors should be buried in the root zone of the plants to be irrigated, because this is where plants will extract water. Burial in the root zone will help ensure adequate turf or landscape quality. For turfgrass, the sensor should typically be buried at about three inches deep.

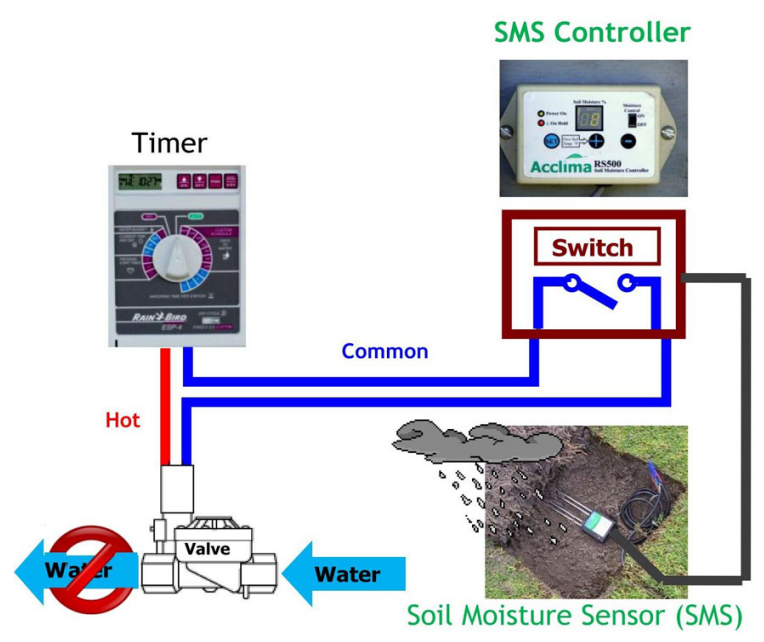

Figure 1. Simplified diagram showing how a soil moisture sensor (SMS) is typically connected to an automated irrigation system. The irrigation timer is connected to a solenoid valve through a hot and a common wire. The common wire is spliced with the SMS system (a controller that acts as a switch, and a sensor buried in the root zone that estimates the soil water content). The SMS takes a reading of the amount of water in the soil and the SMS controller uses that information to open or close the switch. If the soil water content is below the threshold established by the user, the controller will close the switch, allowing power from the timer to reach the irrigation valve and trigger irrigation. In this example the controller opens the switch, bypassing irrigation, because of rainfall wetting the soil around the soil moisture sensor. Credits: Melissa Haley

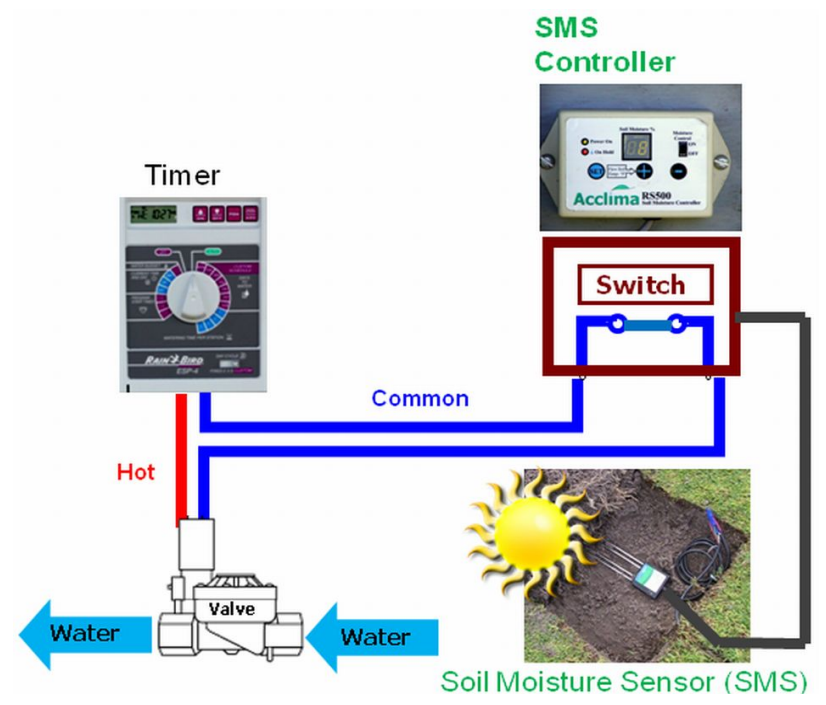

Figure 2. In this example the controller closes the switch allowing irrigation because of dry conditions in the soil around the soil moisture sensor.

- Sensors need to be in good contact with the soil after burial; there should be no air gaps surrounding the sensor. Soil should be packed firmly but not excessively around the sensor. 
- If one sensor is used to control the entire irrigation system, it should be buried in the zone that requires water first, to ensure that all zones get adequate irrigation. Typically, this will be an area with full sun or the area with the most sun exposure.

- Sensors should be placed at least 5 feet from the home, property line, or an impervious surface (such as a driveway) and 3 feet from a planted bed area.

- Sensors should also be located at least 5 feet from irrigation heads and toward the center of an irrigation zone.

- Sensors should not be buried in high traffic areas to prevent excess compaction of the soil around the sensor.

\section{Setting the Sensor Threshold}

Once the sensor has been buried and the SMS controller has been connected to the irrigation system, the sensor needs to be calibrated and/or the soil water content threshold needs to be selected.

Based on the sandy soils in much of Florida, the following steps should be followed to calibrate or select a threshold for the soil moisture sensor controller:

Step 1. Apply water to the area where the sensor is buried. Either set the irrigation zone to apply at least 1 inch of water or use a 5-gallon bucket to apply directly over the buried sensor.

Step 2. Leave the area alone for 24 hours, and do not apply more water. If it rains during the 24 hours, the process should be started over.

Step 3. The water content after 24 hours is now the sensor threshold used to allow or bypass scheduled irrigation events. This threshold may be decreased slightly ( 20\%) to allow more storage for rainfall; however, the landscape will still need to be carefully monitored to ensure that adequate irrigation is being supplied.

The last step may vary slightly for each type of SMS controller. Generally, the manufacturer's instructions should be followed for the actual setup of the controller. These steps are provided mainly to direct how to establish the proper soil moisture content for the specific soil.

Examples of Step 3 for SMS systems commercially available in Florida:

- Acclima Digital TDT® RS500 (Acclima Inc., Meridian, ID) - This controller displays the water content in the soil as a percentage of the volume of the soil. The set point of the controller is the water content of the soil after the 24-hour waiting period. In research on fine sandy soil and St. Augustinegrass at the University of Florida, a set point of $10 \%$ (volumetric water content) was sufficient to ensure adequate turf quality while minimizing wasted irrigation water. In contrast, a set point of $7 \%$ was adequate for bermudagrass turf.

- AquaBluß (Aquaspy, Inc., Santa Ana, CA) The AquaBlu irrigation controller has a dial with relative set-point positions. The leftmost position represents a dryer soil water content and the rightmost position represents a wetter soil water condition. According to the manufacturer, the following procedure should be followed: With the AquaBlu turned "OFF," irrigate the area to the desired level. Turn the AquaBlu "ON," with the dial in the "Left Most" position. Rotate the AquaBlu dial very slowly to the right until the "RED" light goes out. The AquaBlu will now stop irrigation whenever moisture exceeds this value.

- Lawn Logic ${ }^{\circ}$ LL1004 (Alpine Automation, Inc., Aurora, $\mathrm{CO}$ ) - This controller uses relative calibration, meaning the controller has relative set points from \#1 (dry) to \#9 (wet). The calibration of the controller is performed after watering and waiting 24 hours. After calibration a set point from \#1 to \#9 is selected. To maintain both good turf quality and produce water savings, a set point after calibration of \#5 is suggested by researchers at the University of Florida. 
- Moisture Clik ${ }^{\mathrm{TM}}$ IL200-MC (Dynamax, Inc., Houston, TX) - After the 24-hour draining process, the water content is read off the controller with a digital voltmeter, and is considered to be the field capacity (FC) of the soil. This manufacturer recommends using a chart provided by the company to develop a threshold set point. This chart contains various values for maximum allowable depletion (MAD), which is the amount of water that plants are allowed to use from the soil, before irrigation is initiated. The user chosen MAD value is then correlated to the FC of the soil using the chart, and a set point for the controller is then recommended by the manufacturer. For more information about FC and MAD, visit Basic Irrigation Scheduling in Florida http://edis.ifas.ufl.edu/ae111. Testing is ongoing for this controller at the University of Florida.

-WaterTec ${ }^{\mathrm{TM}}$ S100 (Baseline, Meridian, ID) The WaterTec S100 comes with an auto-calibration capability. After the soil has been saturated, the "+""-" and "Bypass" buttons must be held simultaneously for 3 seconds. The screen will flash between "CAL" "24H" and the current moisture reading. The 24 hour auto-calibration function is initiated. The " $24 \mathrm{H}$ "will count down on the hour until the calibration is complete. Watering pauses during this time. It is important that the biSensor does not receive any water during calibration. If the calibration succeeds, the moisture threshold will be automatically set, and the system will allow watering when soil moisture drops below this threshold. Testing is ongoing for this controller at the University of Florida.

\section{Programming the Irrigation Timer with a Soil Moisture Sensor System}

Soil moisture control devices can reduce water use on the lawn by bypassing scheduled irrigation events, but is important to make sure the irrigation schedule is programmed into the irrigation timer correctly. Programming the irrigation timer correctly for the area to be irrigated can make the use of irrigation water more efficient. Before setting the irrigation schedule it is important to determine when the water will be applied and how much to apply with each irrigation event. In most areas of Florida the days per week in which irrigation is allowed is already limited by water restrictions. Irrigation run time is the amount of time an irrigation zone has to be turned on to apply the desired amount of water. It is affected by the water application rate of the irrigation sprinklers and the time of the year. See EDIS publication How To Calibrate Your Sprinkler System http://edis.ifas.ufl.edu/lh026, for information on how to determine the application rate of your system. For more information on setting the irrigation timer properly see Operation of Residential Irrigation Controllers http://edis.ifas.ufl.edu/AE220, which is also provided as a tool in the Florida Automated Weather Network (FAWN) urban irrigation scheduler (http://fawn.ifas.ufl.edu/urban_irrigation/).

Extensive details on soil moisture sensor controller installation and programming can be found in the Field Guide to Soil Moisture Sensor Use in Florida http://www.floridawaterstar.com/pdfs/ SMS_field_guide.pdf.

\section{References}

Dukes, M. D., B. Cardenas-Lailhacar, B., and G.L. Miller. (2005, June). Irrigation Research at UF/IFAS. Retrieved June 27, 2008, from Institute of Food and Agricultural Sciences: http://irrigation.ifas.ufl.edu/SMS/pubs/ June05_Resource_sensor_irrig.pdf.

Florida Department of Environmental Protection. 2002. Florida Water Conservation Initiative. Section 62-40.412(1), F.A.C. Available at http://www.dep.state.fl.us.

Dukes, M.D. and D.Z. Haman,. 2002. Operation of Residential Irrigation Controllers. EDIS. Retrieved July 7, 2008, from Institute of Food and Agricultural Sciences, University of Florida: http://edis.ifas.ufl.edu/AE220.

Haley, M.B., M.D. Dukes, S. Davis, M. Shedd and B. Cardenas-Lailhacar. 2008. Energy Efficient Homes: The Irrigation System. EDIS. Retrieved July 7, 2008, from Institute of Food and Agricultural 
Sciences, University of Florida:

http://edis.ifas.ufl.edu/FY1043.

Mayer, P.W., W.B. DeOreo, E.M. Opitz, J.C. Kiefer, W.Y. Davis, B. Dziegielewski, and J.O. Nelson. 1999. Residential End Uses of Water. American Water Works Association Research Foundation. Denver, CO.

Muñoz-Carpena, R. 2004. Field Devices for Monitoring Soil Water Content. EDIS. Retrieved July 7, 2008, from Institute of Food and Agricultural Sciences, University of Florida: http://edis.ifas.ufl.edu/AE266.

Smajstrla, A.G., B.J. Boman, D.Z. Haman, F.T. Izuno, D.J. Pitts, and F.S. Zazueta. 1997. Basic Irrigation Scheduling in Florida. EDIS. Retrieved July 14, 2008, from Institute of Food and Agricultural Sciences, University of Florida: http://edis.ifas.ufl.edu/AE111.

Trenholm, L.E., J. Bryan Unruh, and J.L. Cisar. 1991. How to Calibrate Your Sprinkler System. EDIS. Retrieved July 14, 2008, from Institute of Food and Agricultural Sciences, University of Florida: http://edis.ifas.ufl.edu/LH026.

University of Florida Program for Resource Efficient Communities. 2007. Field guide to proper installation, calibration and maintenance of soil moisture sensor control systems in residential Florida landscapes. St. Johns River Water Management District: http://www.floridawaterstar.com/pdfs/ SMS_field_guide.pdf. 